CHAPTER 7

\title{
DISCOVERY OF A NEW SANDSTONE WITH RESIDUAL OIL IN MAASTRICHTIAN(?) STRATA AT SHELTER CREEK, LOWER COOK INLET, ALASKA
}

\author{
Robert J. Gillis ${ }^{1}$
}

\section{INTRODUCTION}

Mesozoic sandstones in Cook Inlet basin are commonly thought to possess insufficient primary porosity and permeability (for example, Helmold, 2013; Helmold and others, 2013; Helmold and Stanley, 2015) to host commercial hydrocarbon reservoirs, which has negatively impacted exploration efforts that target these intervals. Nevertheless, local incidences of porosity-hosted oil in Mesozoic strata have been identified in outcrop (for example, Stanley and others, 2013; LePain and others, 2012; Wartes and others, 2013; Wartes and Herriott, 2014, 2015) and in wells (Magoon and Anders, 1992), but controls of their distribution are poorly understood. Most of these occurrences are in more quartz-rich Upper Cretaceous strata found throughout Cook Inlet basin (fig. 7-1; Magoon and others, 1980; Magoon and Anders, 1992; Magoon and Egbert, 1986; LePain and others, 2012; Wartes and others, 2013). This report documents a newly discovered oil-bearing sandstone locality in probable Upper Cretaceous (Maastrichtian[?]) strata on the west side of lower Cook Inlet that was encountered during geologic mapping by the Alaska Division of Geological \& Geophysical Surveys (DGGS) in summer 2015 (see Herriott, 2016 [this volume]). Presented below is a description of this locality at Shelter Creek on the west side of Cook Inlet (figs. 7-2 and 7-3), followed by a brief discussion of the regional distribution and significance of porosityhosted hydrocarbons in Upper Cretaceous strata of Cook Inlet.

\section{BRIEF DESCRIPTION OF MAASTRICHTIAN(?) STRATA AT SHELTER CREEK}

A thin, newly-identified wedge of conglomerate, sandstone with residual oil, siltstone, and silty coal observed at Shelter Creek has characteristics similar to a well-studied nonmarine Maastrichtian interval hosting oil-bearing sandstones near Saddle Mountain (sometimes informally referred to as the Saddle Mountain member or Saddle Mountain section [Magoon and others, 1980; LePain and others, 2012]). The section likely composes part of a thin belt of strata that is discontinuously exposed for about $9.5 \mathrm{~km}$ from east of Hickerson Lake to southeast of Saddle Mountain (fig. 7-2; see also Wilson and others, 2012). The entire Maastrichtian(?) interval at Shelter Creek is only about $7 \mathrm{~m}$ thick (fig. 7-4a) and overlies Upper Jurassic Naknek Formation marine sandstone. An up-to-5-m-thick succession at the base of the interval is composed of clastsupported cobble conglomerate (fig. 7-4b). The upper portion of the Maastrichtian(?) interval consists of an approximately 80-cm-thick, light tan- to buff-colored, tabular, fine-grained, arkosic sandstone that is overlain by an approximately 80-cmthick succession of siltstone. The Maastrichtian(?) interval is capped by a 5-10-cm-thick, highly carbonaceous siltstone to bony coal (figs. 7-4b and 7-4c). The upper several centimeters of the undisturbed sandstone bed emits a faint, fleeting petroliferous odor that is strong and persistent from freshly broken surfaces. The sandstone is mostly massive, but includes weakly expressed, very thin, concave-up partings in the upper $35 \mathrm{~cm}$ consistent with preferentially weathered ripple laminations. This sandstone is moderately well indurated, contrasting with other occurrences of Maastrichtian sandstones with residual oil that are friable, presumably because hydrocarbon migration preceded cementation (LePain and others, 2012). The Maastrichtian(?) strata are overlain by more than $100 \mathrm{~m}$ of poorly organized cobble conglomerate of the Paleogene West Foreland Formation (figs. 7-3 and 7-4). Although the two conglomeratic units have similar volcanic and volcaniclastic clast compositions, the Maastrichtian(?) conglomerate contains a higher percentage of plutonic clasts ( $20 \%$ vs. $\sim 10 \%$, respectively), perhaps suggesting a more quartz-rich, dissected arc provenance for the former.

\section{STRATIGRAPHIC RELATIONSHIP BETWEEN MAASTRICHTIAN(?) STRATA AND OVERLYING/UNDERLYING UNITS}

Upper Cretaceous strata in Cook Inlet basin are bounded by regional unconformities that are locally well expressed in the study area (see fig. 7-2 for location). Here, Maastrichtian(?) strata unconformably overlie a uniform dip panel of wellindurated Naknek Formation sandstone and are separated from overlying West Foreland Formation conglomerate by a complex, undulating unconformity (figs. 7-5a and 7-5b). The unconformity often erosionally removes the Maastrichtian(?) rocks altogether and places West Foreland conglomerates directly on the Naknek strata (fig. 7-5a), forming thin, tapering lenses of Upper Cretaceous rocks (fig. 7-2). Magoon and others (1980) reported 14 degrees of fanning bedding discordance between Naknek and Maastrichtian strata and 10 degrees of discordance between Maastrichtian strata and West Foreland

\footnotetext{
${ }^{1}$ Alaska Division of Geological \& Geophysical Surveys, 3354 College Rd., Fairbanks, AK 99709-3707; robert.gillis@alaska.gov
} 


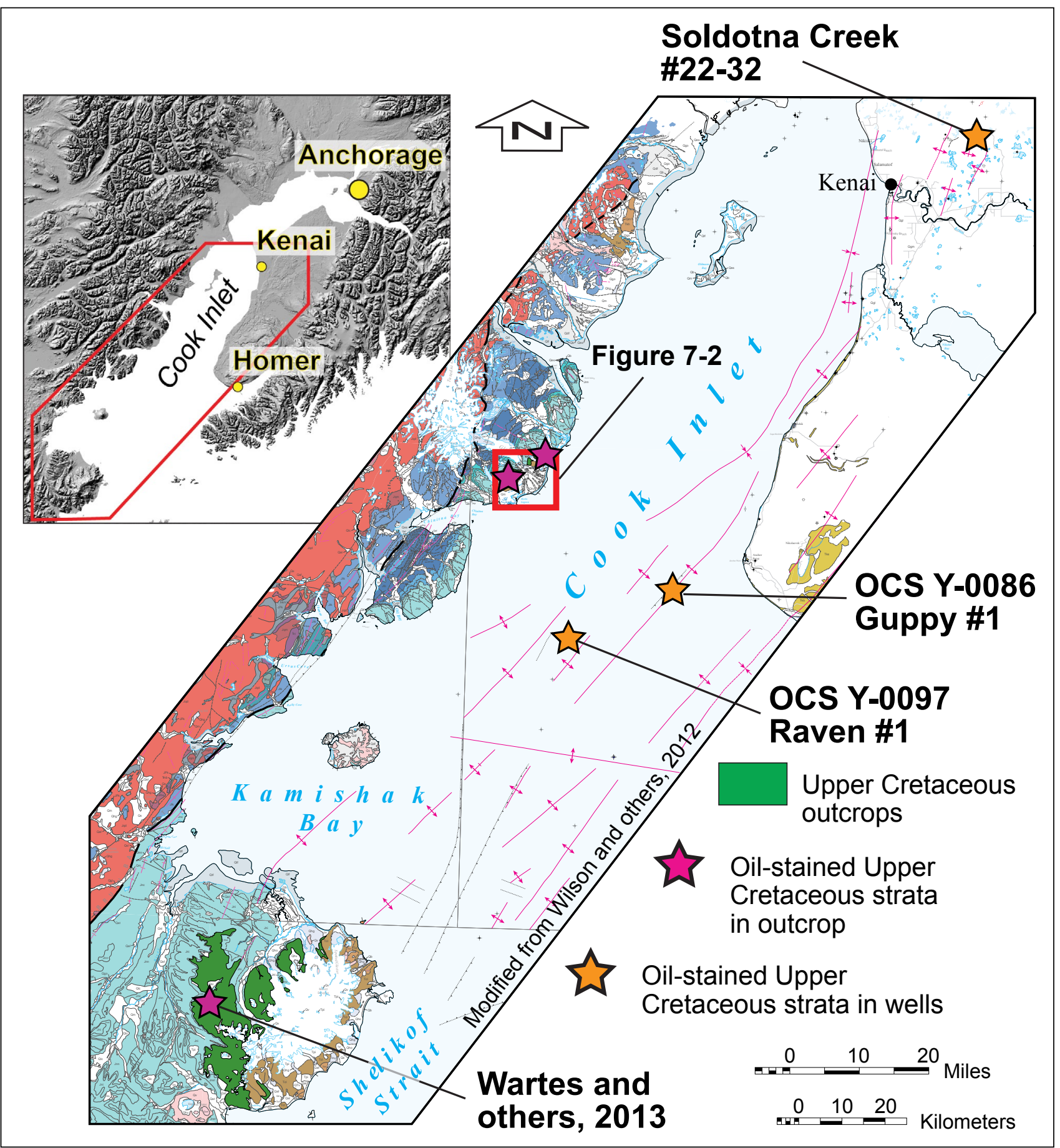

Figure 7-1. Simplified geologic map of lower Cook Inlet, modified from Wilson and others (2012), showing distribution of Upper Cretaceous rock outcrops (dark green polygons), distribution of known oil-saturated Upper Cretaceous sandstones in outcrop (magenta stars), and distribution of Cook Inlet wells in which oil-saturated sandstones and liquid hydrocarbons were encountered in Upper Cretaceous rocks (orange stars). Note the broad distribution of Upper Cretaceous sandstones throughout the basin that possess porosity-hosted hydrocarbons. Field study area defined by red box. 


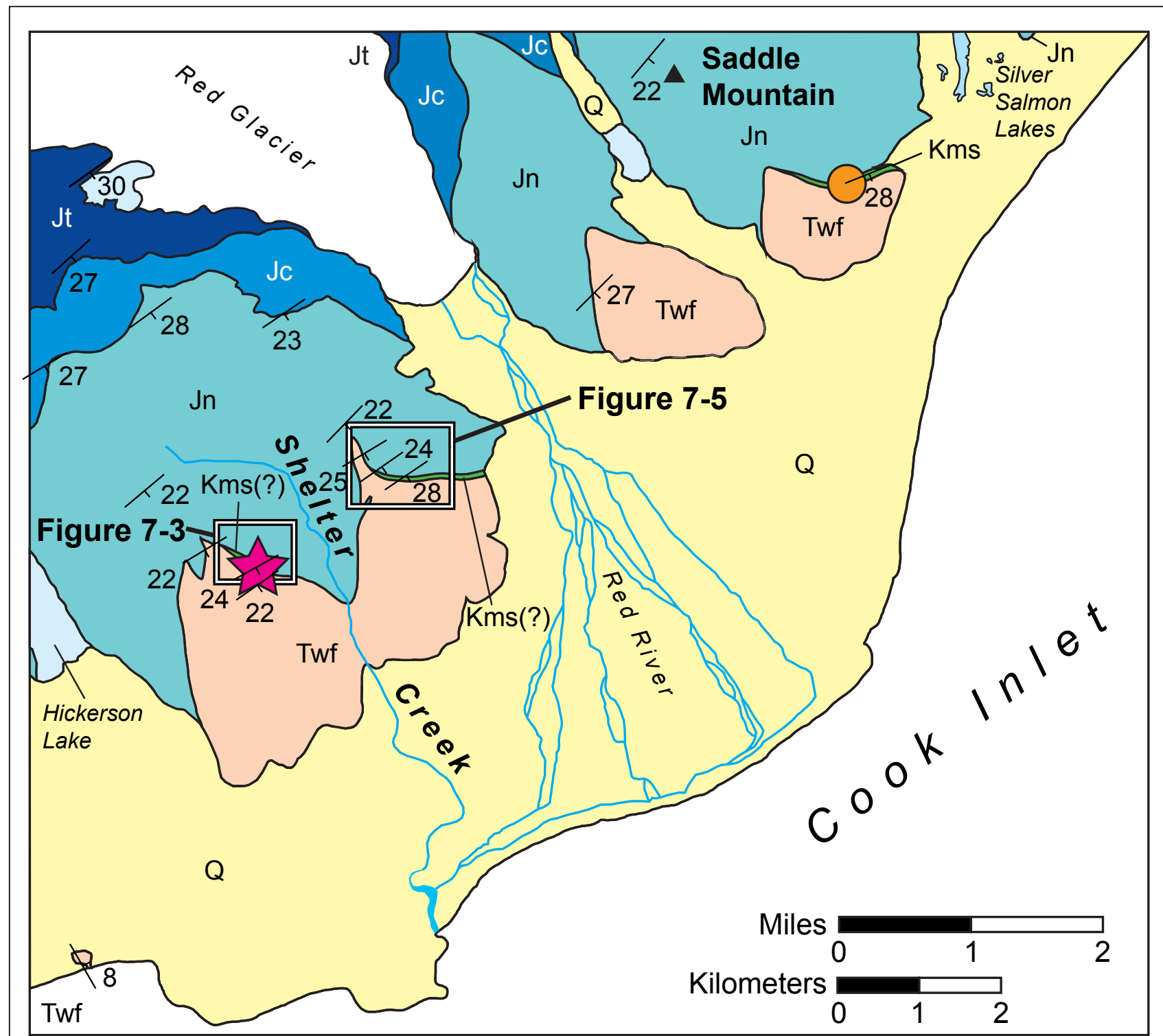

\begin{tabular}{|c|c|}
\hline 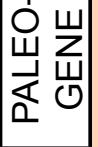 & $\begin{array}{l}\text { West Foreland } \\
\text { Formation } \\
\text { (Twf) }\end{array}$ \\
\hline U. CRET. & $\mathrm{Kms}$ \\
\hline 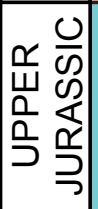 & $\begin{array}{l}\text { Naknek } \\
\text { Formation } \\
\text { (Jn) }\end{array}$ \\
\hline \multirow{2}{*}{ 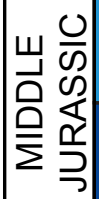 } & $\begin{array}{c}\text { Chinitna } \\
\text { Formation (Jc) }\end{array}$ \\
\hline & $\begin{array}{l}\text { Tuxedni } \\
\text { Group (Jt) }\end{array}$ \\
\hline
\end{tabular}

\section{5 oil-stained sandstone location} strata (queried where age is uncertain)

Saddle Mountain oil-stained sandstone location (Magoon and others, 1980; LePain and others, 2012)

Figure 7-2. Geologic map showing the distribution of Upper Cretaceous strata on the west side of lower Cook Inlet. Map simplified from new 1:63,360-scale field mapping by DGGS in summer 2015. Magenta star indicates the location of a newly identified occurrence of oil-saturated sandstone in Maastrichtian(?)-age strata. The orange circle indicates the location of an occurrence of Maastrichtian rocks hosting residual oil previously identified by LePain and others (2012). These strata are interpreted to represent a once continuous succession of Upper Cretaceous strata that was erosionally dissected prior to Cenozoic nonmarine deposition. 
Formation, suggesting progressive tilting of the basin margin since Late Jurassic. However, this study documents that over the length of outcrops that extend several tens to hundreds of meters, depositional surfaces are commonly subparallel between units (fig. 7-5a). This is supported by 69 bedding orientation measurements from all three units that indicate relatively uniform attitudes, implying that southeast tilting of the entire stratigraphic package by about 22-24 degrees occurred after Paleogene time.

\section{SIGNIFICANCE OF WIDESPREAD OCCURRENCE OF OIL IN UPPER CRETACEOUS ROCKS OF COOK INLET}

Maastrichtian(?) rocks at Shelter Creek and near Saddle Mountain represent the northernmost outcrops of Upper Cretaceous strata known in the Cook Inlet basin. The nearest sedimentary outcrops of equivalent age are marine Kaguyak Formation strata on the upper Alaska Peninsula (Riehle and others, 1993) approximately $130 \mathrm{~km}$ due southwest of the study area (fig. 7-1), which are also locally oil bearing (Wartes and others, 2013). Despite being only discontinuously exposed at the surface, Upper Cretaceous strata occur in the offshore subsurface throughout much of the Cook Inlet basin (Boss and others, 1976; Magoon and Egbert, 1986; Magoon and Anders, 1992; Gregerson and Shellenbaum, in press). Although relatively few Cook Inlet wells penetrate Mesozoic strata, drill stem tests of three such wells (fig. 7-1) produced non-commercial amounts of oil from Upper Cretaceous rocks (Magoon and Anders, 1992). The wide distribution of Upper Cretaceous sandstones with oil shows in Cook Inlet basin suggests that these strata might be viable conventional reservoir rocks in the underexplored Mesozoic stratigraphy.

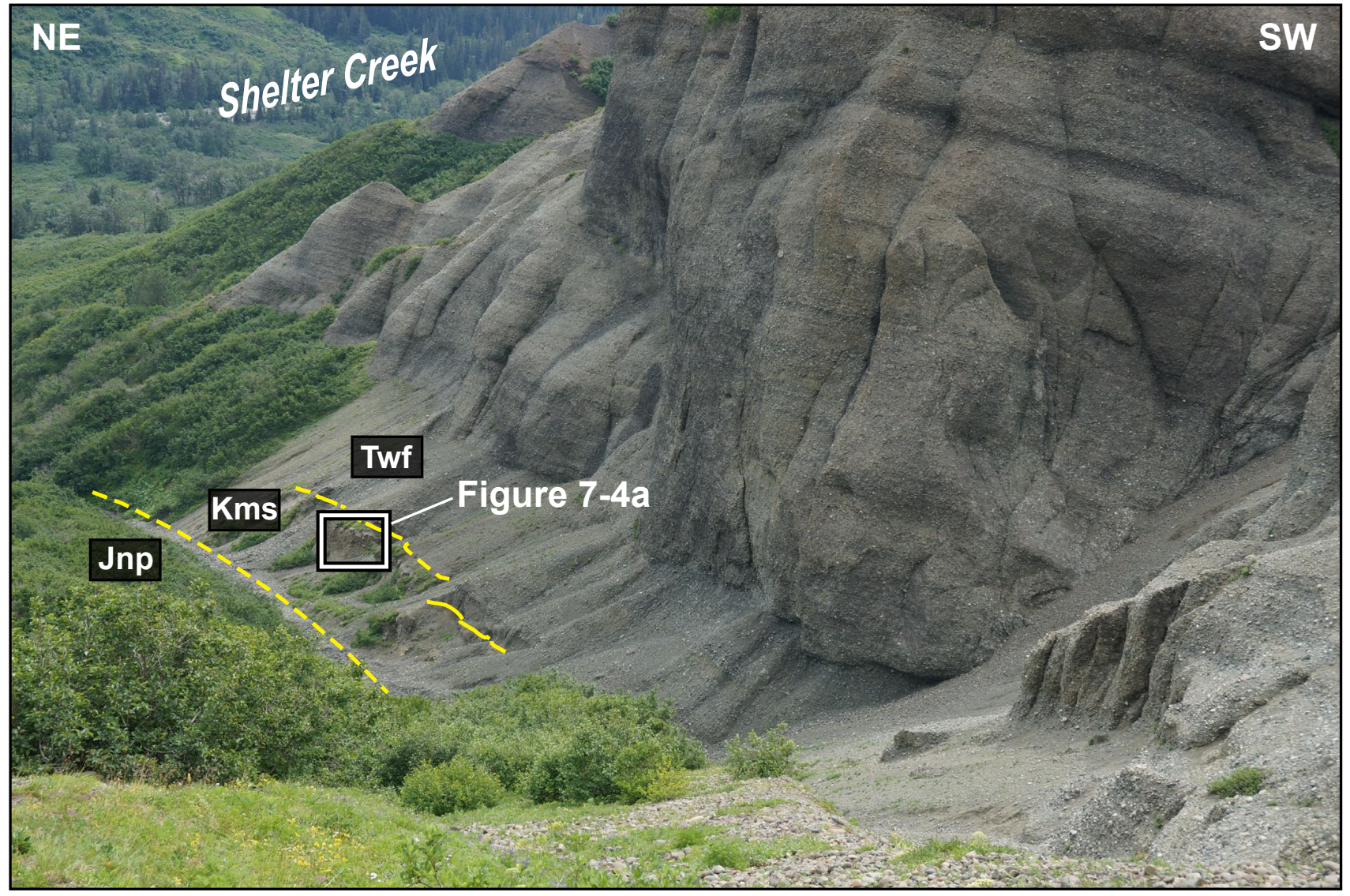

Figure 7-3. View, looking due southeast, from near the headwaters of Shelter Creek toward Cook Inlet. A thin succession of Maastrichtian(?) strata unconformably overlies Upper Jurassic Naknek Formation marine sandstone and unconformably underlies a thick succession of Paleogene West Foreland Formation nonmarine conglomerate. White box frames area of detailed images of a Maastrichtian(?) sandstone interval hosting residual oil (fig. 7-4). Jnp = Naknek Formation (Pomeroy Arkose Member), Kms = Maastrichtian(?) strata, $\mathrm{Twf}=$ West Foreland Formation. Yellow lines (dashed where inferred) represent formation contacts. See figure 7-2 for location context. 

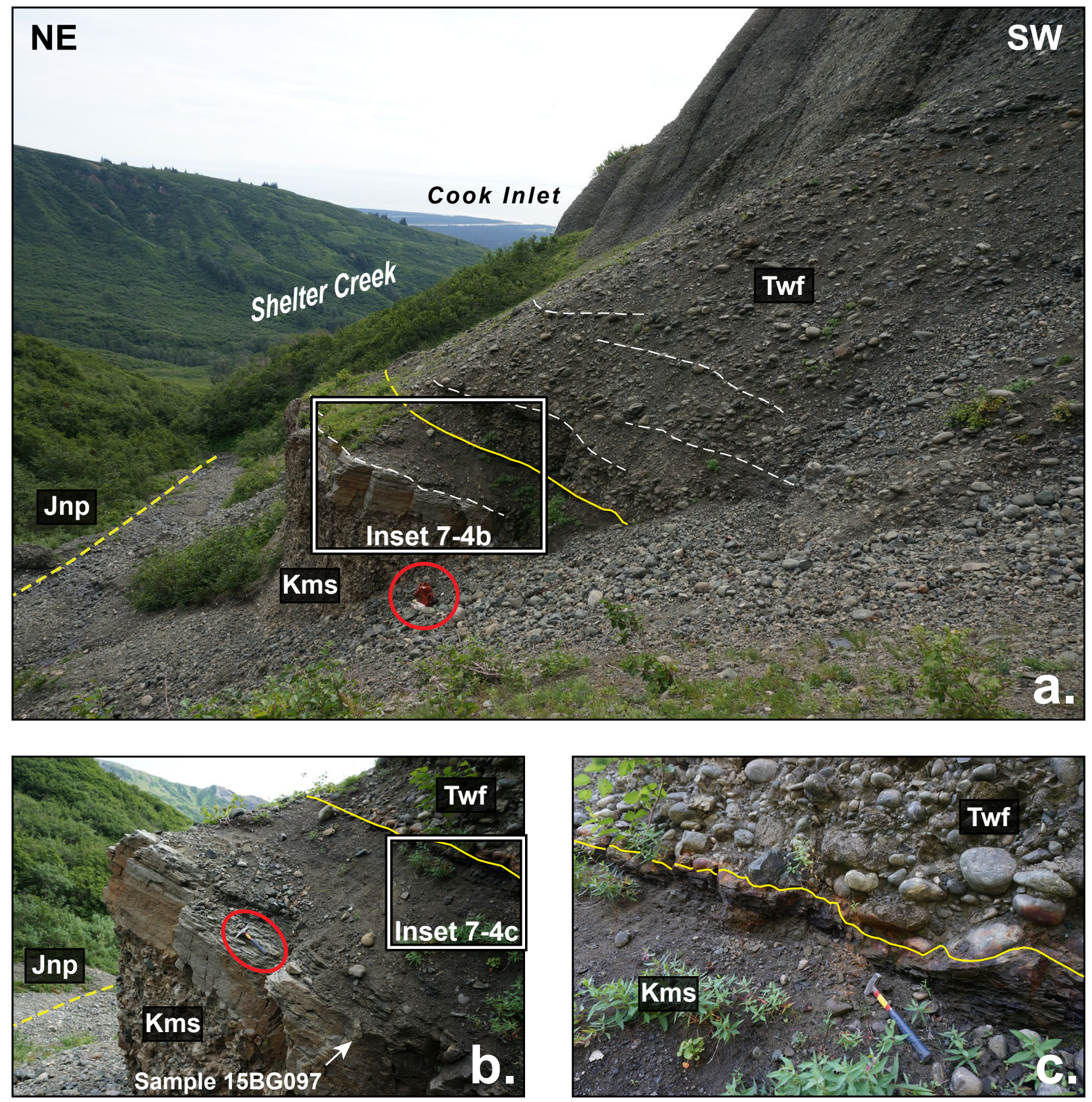

Figure 7-4. Detailed views, looking due southeast, at the Shelter Creek Maastrichtian(?) section. Yellow lines represent formation contacts and white lines represent traceable bedding surfaces; dashed lines are inferred. Jnp = Upper Jurassic Naknek Formation (Pomeroy Arkose Member), Kms = Maastrichtian(?) strata, Twf = West Foreland Formation. See figure 7-2 for location context. a. An up-to-5-m-thick succession of conglomerate overlying a uniform Naknek Formation dip slope is capped by an approximately 80-cm-thick sandstone bed that emits a faint petroliferous odor. Backpack (in red circle) for scale. $\boldsymbol{b}$. A sample (15BG097) for organic geochemical analysis was collected near the top of the sandstone bed, from the interval where a petroliferous odor is most strongly emitted. Sandstone bed transitions from massive to ripple cross-laminated in the upper $35 \mathrm{~cm}$. The sandstone bed is moderately well indurated throughout, unlike other reported occurrences of remnant oil-bearing Upper Cretaceous sandstones that are friable (LePain and others, 2012), possibly suggesting that cementation occurred prior to hydrocarbon migration at this location. Hammer (in red oval) for scale. c. Uppermost Maastrichtian(?) interval and contact with overlying West Foreland Formation. Highly carbonaceous siltstone and bony coal compose the upper 5-10 cm of the Maastrichtian(?) succession. The irregular contact with the overlying West Foreland Formation at this location is non-or minimally erosive and appears to be concordant with overlying and underlying bedding surfaces. 


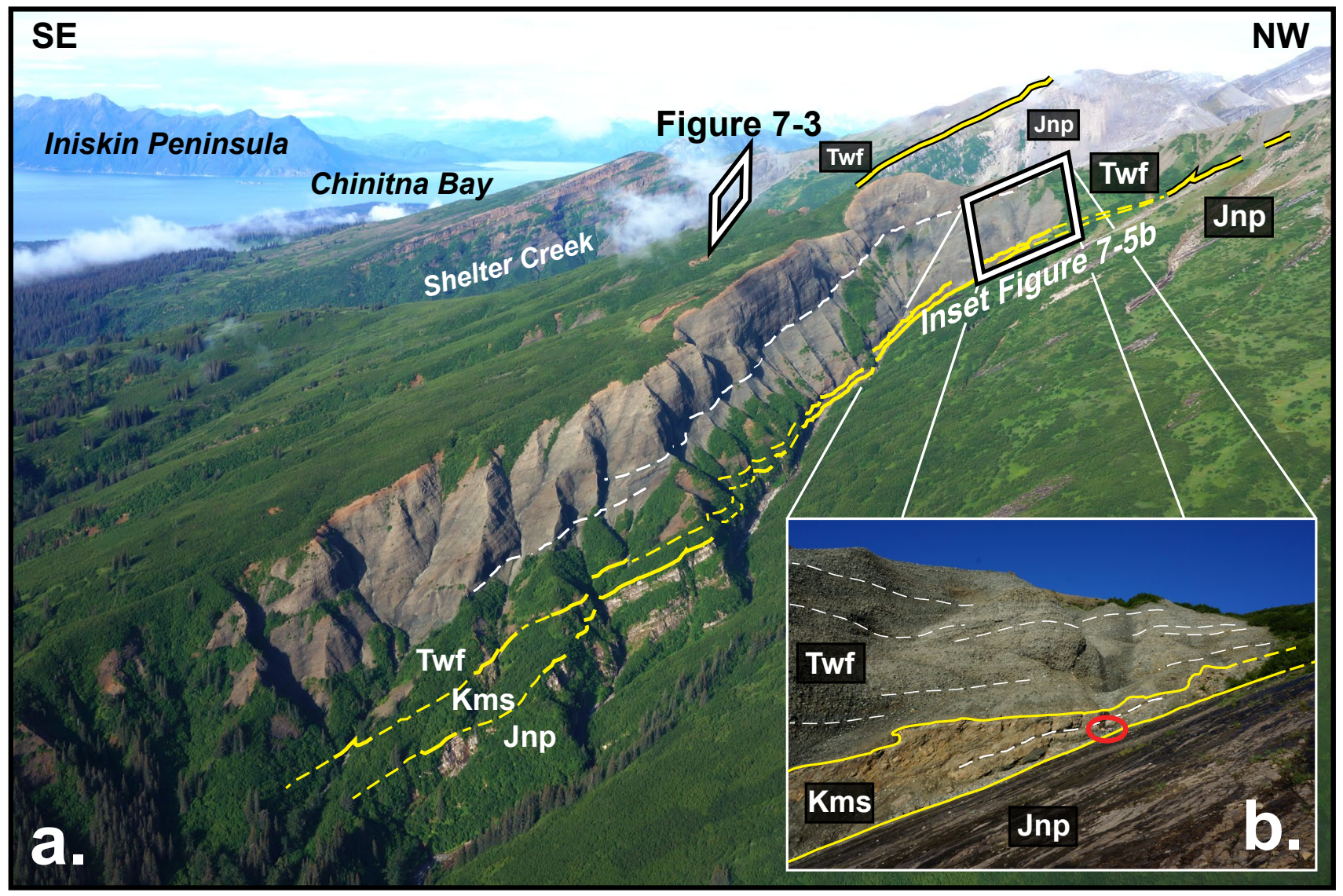

Figure 7-5. a. View, looking due southwest toward Chinitna Bay, across two flatirons of southeast-tilted Naknek Formation, Maastrichtian(?), and West Foreland Formation strata. Unnamed creek in the foreground drains into the Red River (see fig. 7-2); Shelter Creek appears in the middle ground. Formation contacts represented as yellow lines (dashed where inferred). Major stratigraphic horizons in West Foreland Formation conglomerates are marked with heavy dashed white lines. Jnp = Upper Jurassic Naknek Formation (Pomeroy Arkose Member), $\mathrm{Kms}=$ Maastrichtian(?) strata, Twf = Paleocene(?) to Eocene West Foreland Formation. In both creeks, Jnp forms a remarkably uniform dip slope, and Twf cuts downsection upslope, removing Kms and directly juxtaposing Twf and Jnp. A well-defined Twf stratal surface parallels Jnp for hundreds of meters, indicating that both were subhorizontal during Twf deposition. Sixty-eight bedding orientations measured from all three units in this view suggest little regional bedding angularity between the formations. $\boldsymbol{b}$. Detailed view of Jnp/Kms/Twf contacts, highlighting the uniform Jnp dip slope, concordant Jnp/Kms contact and subparallel deposition of Kms, and erosive $\mathrm{Kms} / \mathrm{Twf}$ contact that thins $\mathrm{Kms}$ upslope to the northwest. Thin dashed white lines in represent traceable bedding surfaces. Two geologists (sitting, in red oval) for scale. See figure 7-2 for location context. 


\section{ACKNOWLEDGMENTS}

Thanks to Dave LePain, Marwan Wartes, Rick Stanley, Paul Decker, and Paul Betka for discussions about the Maastrichtian strata with respect to geologic field relationships and Cook Inlet petroleum systems. This report benefited from careful reviews by David LePain and Trystan Herriott. The project staff appreciated the skillful flying of helicopter pilot Merlin "Spanky" Handley and hospitality of Eli and Jenny Porter and the staff at Snug Harbor Wilderness Lodge. We are grateful to Buck Mangipane and Jeff Shearer at Lake Clark National Park and Preserve for shepherding our permit through promptly, and Jason Brune and Tanisha Gleason of Cook Inlet Region, Inc., for the same. We appreciate the support of the following Alaska Native village corporations for their support in letting us work on their lands: Chickaloon, Knik, Ninilchik, Salamatof, Seldovia, and Tyonek. Funding for fieldwork was provided by the Alaska Division of Geological \& Geophysical Surveys and by the U.S. Geological Survey's Cooperative Geologic Mapping Program (STATEMAP awards G13AC00157 and G15AC00199).

\section{REFERENCES CITED}

Boss, R.F., Lennon, R.B., and Wilson, B.W., 1976, Middle Ground Shoal oil field, Alaska, in Braunstein, Jules, ed., North American oil and gas fields: American Association of Petroleum Geologists Memoir 24, p. 1-22.

Gregersen, L.S., and Shellenbaum, D.P., in press, Top Mesozoic unconformity subcrop map, Cook Inlet basin, Alaska: Alaska Division of Geological \& Geophysical Surveys, Report of Investigations 2016-XX, 1 sheet, scale 1:500,000.

Helmold, K.P., 2013, Reservoir quality of sandstones in the Naknek and Kaguyak Formations-Field observations, in Gillis, R.J., ed., Overview of 2012 field studies - Upper Alaska Peninsula and west side of lower Cook Inlet, Alaska: Alaska Division of Geological \& Geophysical Surveys Preliminary Interpretive Report 2013-1C, p. 11-12. doi:10.14509/24846

Helmold, K.P., and Stanley, R.G., 2015, Petrology and reservoir quality of the Gaikema Sandstone-Initial impressions, in Wartes, M.A., ed., Energy-related studies during the 2014 field season, western Cook Inlet, Alaska: Alaska Division of Geological \& Geophysical Surveys Preliminary Interpretive Report 2015-5-7, p. 43-48. doi:10.14509/29462

Helmold, K.P., LePain, D.L., Wilson, M.D., and Peterson, C.S., 2013, Petrology and reservoir potential of Tertiary and Mesozoic sandstones, Cook Inlet, Alaska-A preliminary analysis of outcrop samples collected during 2007-2010 field seasons: Alaska Division of Geological \& Geophysical Surveys Preliminary Interpretive Report 2013-5, 34 p. doi: $\underline{10.14509 / 25035}$

Herriott, T.M., ed., 2016 (this volume), Petroleum-related geologic studies in lower Cook Inlet during 2015, Iniskin-Tuxedni region, south-central Alaska: Alaska Division of Geological \& Geophysical Surveys Preliminary Interpretive Report 2016-1, 78 p. doi:10.14509/29532

LePain, D.L., Lillis, P.G., Helmold, K.P., and Stanley, R.G., 2012, Migrated hydrocarbons in exposure of Maastrichtian nonmarine strata near Saddle Mountain, lower Cook Inlet, Alaska: Alaska Division of Geological \& Geophysical Surveys Report of Investigations 2012-1, 13 p. doi:10.14509/23943

Magoon, L.B., and Anders, D.E., 1992, Oil-to-source-rock correlation using carbon-isotopic data and biological marker compounds, Cook Inlet-Alaska Peninsula, Alaska, in Moldowan, J.M., Albrecht, Pierre, and Philp, R.P., eds., Biological markers in sediments and petroleum: Englewood Cliffs, N.J., Prentice-Hall, p. 241-274.

Magoon, L.B., and Egbert, R.M., 1986, Framework geology and sandstone composition, in Magoon, L.B., ed., Geologic studies of the lower Cook Inlet COST No. 1 well, Alaska outer continental shelf: U.S. Geological Survey Bulletin 1596, p. 65-90.

Magoon, L.B., Griesbach, F.B., and Egbert, R.M., 1980, Nonmarine Upper Cretaceous rocks, Cook Inlet, Alaska: AAPG Bulletin, v. 64, no. 8, p. 1,259-1,266.

Riehle, J.R., Detterman, R.L., Yount, M.E., and Miller, J.W., 1993, Geologic map of the Mount Katmai Quadrangle and adjacent parts of the Naknek and Afognak quadrangles, Alaska: U.S. Geological Survey Miscellaneous Investigations Series Map 2204, 1 sheet, scale 1:250,000.

Stanley, R.G., Herriott, T.M., Helmold, K.P., Gillis, R.J., and Lillis, P.G., 2013, Hydrocarbon-bearing sandstone in the Upper Jurassic Naknek Formation on the south shore of Kamishak Bay, in Gillis, R.J., ed., Overview of 2012 field studies-Upper Alaska Peninsula and west side of lower Cook Inlet, Alaska: Alaska Division of Geological \& Geophysical Surveys Preliminary Interpretive Report 2013-1E, p. 19-23. doi:10.14509/24848

Wartes, M.A., and Herriott, T.M., 2014, Discovery of oil-stained sandstone within the Chinitna Formation, northern Iniskin Peninsula, in Gillis, R.J., ed., Cook Inlet program 2013 field studies - Observations and preliminary interpretations from new 1:63,360-scale geologic mapping of the Iniskin Peninsula, lower Cook Inlet, Alaska: Alaska Division of Geological \& Geophysical Surveys Preliminary Interpretive Report 2014-2-6, p. 29-31. doi:10.14509/27311 
Wartes, M.A., and Herriott, T.M., 2015, Oil-stained sandstone in the Middle Jurassic lower Paveloff Siltstone Member of the Chinitna Formation: Exploring the potential role of facies variations in controlling diagenesis and reservoir quality in western Cook Inlet, Alaska: Alaska Division of Geological \& Geophysical Surveys Preliminary Interpretive Report 2015-7, 9 p. doi:10.14509/29533

Wartes, M.A., Decker, P.L., Stanley, R.G., Herriott, T.M., Helmold, K.P., and Gillis, R.J., 2013, Preliminary stratigraphy and facies analysis of the Upper Cretaceous Kaguyak Formation, including a brief summary of newly discovered oil stain, upper Alaska Peninsula, in Gillis, R.J., ed., Overview of 2012 field studies-Upper Alaska Peninsula and west side of lower Cook Inlet, Alaska: Alaska Division of Geological \& Geophysical Surveys Preliminary Interpretive Report 2013-1F, p. 25-32. doi: 10.14509/24849

Wilson, F.H., Hults, C.P., Schmoll, H.R., Haeussler, P.J., Schmidt, J.M., Yehle, L.A., and Labay, K.A., compilers, 2012, Geologic map of the Cook Inlet region, Alaska, including parts of the Talkeetna, Talkeetna Mountains, Tyonek, Anchorage, Lake Clark, Kenai, Seward, Iliamna, Seldovia, Mount Katmai, and Afognak: U.S. Geological Survey Scientific Investigations Map 3153, 76 p., 2 sheets, scale 1:250,000. 